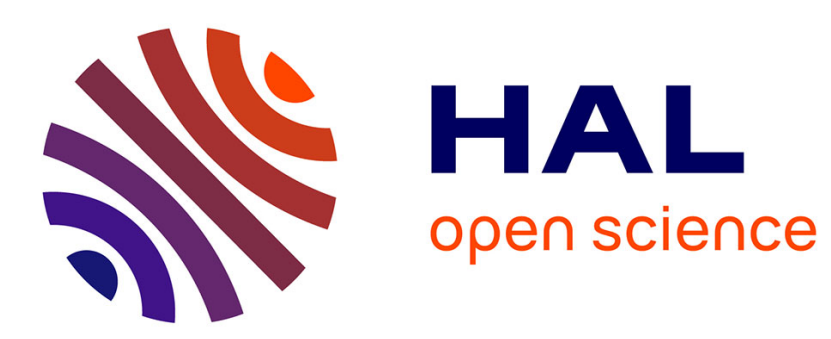

\title{
Somatostatin and alzheimer's disease
}

E. Burgos-Ramos, A. Hervás-Aguilar, D. Aguado-Llera, L. Puebla-Jiménez, A.M. Hernández-Pinto, V. Barrios, E. Arilla-Ferreiro

\section{To cite this version:}

E. Burgos-Ramos, A. Hervás-Aguilar, D. Aguado-Llera, L. Puebla-Jiménez, A.M. Hernández-Pinto, et al.. Somatostatin and alzheimer's disease. Molecular and Cellular Endocrinology, 2008, 286 (1-2), pp.104. 10.1016/j.mce.2008.01.014 . hal-00531986

\section{HAL Id: hal-00531986 https://hal.science/hal-00531986}

Submitted on 4 Nov 2010

HAL is a multi-disciplinary open access archive for the deposit and dissemination of scientific research documents, whether they are published or not. The documents may come from teaching and research institutions in France or abroad, or from public or private research centers.
L'archive ouverte pluridisciplinaire HAL, est destinée au dépôt et à la diffusion de documents scientifiques de niveau recherche, publiés ou non, émanant des établissements d'enseignement et de recherche français ou étrangers, des laboratoires publics ou privés. 


\section{Accepted Manuscript}

Title: Somatostatin and alzheimer's disease

Authors: E. Burgos-Ramos, A. Hervás-Aguilar, D.

Aguado-Llera, L. Puebla-Jiménez, A.M. Hernández-Pinto, V.

Barrios, E. Arilla-Ferreiro

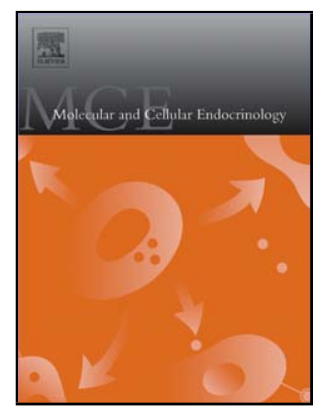

PII:

S0303-7207(08)00020-8

DOI: doi:10.1016/j.mce.2008.01.014

Reference: MCE 6798

To appear in: Molecular and Cellular Endocrinology

Received date: 11-6-2007

Revised date: 23-1-2008

Accepted date: 24-1-2008

Please cite this article as: Burgos-Ramos, E., Hervás-Aguilar, A., Aguado-Llera, D., Puebla-Jiménez, L., Hernández-Pinto, A.M., Barrios, V., Arilla-Ferreiro, E., Somatostatin and alzheimer's disease, Molecular and Cellular Endocrinology (2007), doi:10.1016/j.mce.2008.01.014

This is a PDF file of an unedited manuscript that has been accepted for publication. As a service to our customers we are providing this early version of the manuscript. The manuscript will undergo copyediting, typesetting, and review of the resulting proof before it is published in its final form. Please note that during the production process errors may be discovered which could affect the content, and all legal disclaimers that apply to the journal pertain. 


\section{SOMATOSTATIN AND ALZHEIMER'S DISEASE}

E. Burgos-Ramos ${ }^{\mathrm{a}, \mathrm{b}}$, A. Hervás-Aguilar ${ }^{\mathrm{a}}$, D. Aguado-Llera ${ }^{\mathrm{a}}$, L. Puebla-Jiménez ${ }^{\mathrm{a}}$, A.M. Hernández-Pinto $^{\mathrm{a}}$, V. Barrios ${ }^{\mathrm{b}}$, E. Arilla-Ferreiro ${ }^{\mathrm{a}^{*}}$

a Unidad de Neurobioquímica, Departamento de Bioquímica y Biología Molecular, Facultad de Medicina, Universidad de Alcalá. E-28871 Alcalá de Henares, Madrid, Spain.

${ }^{\mathrm{b}}$ CIBER Fisiopatología, Obesidad y Nutrición (CB06/03), Instituto de Salud Carlos III, Avda. Menéndez Pelayo 65, E-28009, Madrid.

*Corresponding Author

Eduardo Arilla Ferreiro

Departamento de Bioquímica y Biología Molecular, Facultad de Medicina, Universidad de Alcalá. Crta. Madrid-Barcelona Km 33,600, E-28871 Alcalá de Henares, Madrid, Spain.

Tel.: 34-91-885 4509

Fax: 34-91-885 4585

e-mail: eduardo.arilla@uah.es 


\begin{abstract}
Alzeimer's disease (AD) is characterized by the cerebral deposition of senile plaques that are mainly composed of a set of peptides referred to as amyloid $\beta$-peptides $(\mathrm{A} \beta)$. Among the numerous neuropeptides produced in intrinsic cortical and hippocampal neurons, somatostatin (SRIF) has been found to be the most consistently reduced in the brain and cerebrospinal fluid of AD patients. SRIF receptors (SSTR), which mediate the neuromodulatory signals of SRIF, are also markedly depleted in the $\mathrm{AD}$ brain, there being subtype-selective alterations in cortical areas. In the rat temporal cortex, we have shown that intracerebroventricular infusion of $A \beta 25-35$ results in a decrease in SRIF-like immunoreactivity and in SRIF receptor subtype 2 (SSTR2) mRNA and protein levels, in correlation with a decrease in SSTR functionality. Insulinlike growth factor-I prevents the reduction in these parameters induced by $\mathrm{A} \beta 25-35$. A $\beta$ has recently been demonstrated to be degraded primarily by a neutral endopeptidase, neprilysin, in the brain. SRIF regulates brain $A \beta$ levels via modulation of neprilysin activity. Because SRIF expression in the brain declines upon aging in various mammals, including rodents, apes and humans, the aging-dependent reduction of SRIF has been hypothesized to trigger accumulation of $A \beta$ in the brain by supressing neprilysin action. Here we present an overview of recent advances on the role of SRIF in AD and its relationship with $\mathrm{A} \beta$ peptides.
\end{abstract}




\section{ALZHEIMER'S DISEASE AND AMYLOID $\beta$-PEPTIDE}

Alzheimer's disease (AD) is an irreversible neurodegenerative disorder affecting predominantly individuals over age 65 . It is characterized clinically by progressive dementia and, histopathologically, by the presence of extracellular deposits of amyloid fibrils in the core of senile plaques, intracellular neurofibrillar tangles and neuronal cell loss (Braak et al., 1991; Selkoe, 2001). One of the principal components of senile plaques, amyloid $\beta$-peptide $(A \beta)$, is considered to be involved in the pathogenesis of AD (Hsiao et al., 1996; Selkoe, 2001). A $\beta$ peptides are formed from the amyloid precursor protein (APP) by sequential enzymatic processing. Proteolysis by a $\beta$-secretase cleaves APP to yield a membrane-bound C-terminal fragment of APP designated CTF $\beta$. This fragment is subsequently cleaved within the transmembrane domain by $\gamma$-secretase to release $A \beta$ peptides, mainly $A \beta 1-40$ and $A \beta 1-42$, and CTF $\gamma$ peptides (Sambamurti et al., 2002). A $\beta 25-35$, located at the C-terminus of $A \beta 1-42$, has been proposed to be the functional domain of $A \beta$ responsible for its neurotoxic properties (Pike et al., 1993). For many years, the presence of this 11-aminoacid fragment in vivo was questioned. In 2002, Kubo et al. provided evidence that insoluble A $\beta 1-40$, present in the senile plaques characteristic of $\mathrm{AD}$, can be racemized at $\mathrm{Ser}^{26}$, possibly during the aging process, to yield soluble [D-Ser $\left.{ }^{26}\right] \mathrm{A} \beta 1-40$; this fragment is released from the plaques and degraded by proteases, generating the toxic fragments $\left[\mathrm{D}-\mathrm{Ser}^{26}\right] \mathrm{A} \beta 25-35$ and $\left[\mathrm{D}-\mathrm{Ser}^{26}\right] \mathrm{A} \beta 25-40$, both protease-resistant. Immunohistochemical analysis with specific antibodies to [D$\left.\mathrm{Ser}^{26}\right] \mathrm{A} \beta 25-35$ and $\left[\mathrm{D}-\mathrm{Ser}^{26}\right] \mathrm{A} \beta 25-40$ clearly revealed the presence of both fragments in the AD brain but not in age-matched control brains (Kubo et al., 2002). An accumulation of $\mathrm{A} \beta$ peptides has been associated with progressive neuronal death, cognitive deficits and neuropsychiatric disorders such as agitation, apathy and increased 
anxiety (Hardy et al., 1992; Selkoe, 1996; Sheuner et al., 1996; Weiner et al., 1997; Stepanichev et al., 2000).

It is still unclear how $A \beta$ causes its damage, although several mechanisms have been proposed (Bossy-Wetzel et al., 2004). One view suggests that A $\beta$ protofibrils activate microglia, inciting an inflammatory response and release of neurotoxic cytokines (Stewart et al., 1997; Weggen et al., 2001). A $\beta$ protofibrils may also trigger excessive release of excitatory aminoacids, like glutamate, from glial cells and thus may injure nearby neurons by excitotoxicity (Lipton et al., 2004). A third view suggests that protofibrils and aggregates convey harmful effects to neurons by paralyzing axonal and dendritic transport. A $\beta$ deposits may act as non-specific "roadblocks" representing a physical transport barrier (Lipton, 2004; Kamal et al., 2000: Pigino et al., 2003). An additional mechanism of $\mathrm{A} \beta$ injury is synaptic dysfunction and loss, which are early events in AD and occur before amyloid plaque formation (Selkoe, 2002). Alternatively, A $\beta$ may mediate harmful effects by binding redox-reactive metals which, in turn, release free radicals (Bush et al., 1993; Lovell et al., 1998; Bush, 2003; Dong et al., 2003). In addition, oxidative stress from mitochondrial dysfunction occurs early in AD, and $\mathrm{A} \beta$ may directly or indirectly injure mitochondria (Hirai et al, 2001; Casley et al., 2002; Anandatheerthavarada et al., 2003; Lustbader et al., 2004).

In recent years, evidence has accumulated indicating that $\mathrm{A} \beta$ may inhibit ubiquitinated protein degradation by the proteosome (Gregori et al., 1995). The ubiquitin-proteosome system itself plays an important role in apoptosis (Orlowski, 1999; Moore et al., 2003; Hernández et al., 2004). Recent studies report that extracellular $A \beta$ can enter the cytoplasm and inhibit the proteosome of neurons from Tg2576 mice (Oh et al., 2005). Furthermore, accumulation of A $\beta$ within Tg2576 primary neurons leads to impairments in proteosome and ubiquitination activities 
(Almeido et al., 2006). Recently, Tseng et al. (2007) have shown that A $\beta$ oligomers, but not monomers, inhibit the proteosome in vitro and that proteosomal activity is impaired in 3xTg-AD mice when $\mathrm{A} \beta$ oligomer levels are high. In addition, these authors have demonstrated that inhibiting proteosome function in vivo in the $3 \mathrm{xTg}-\mathrm{AD}$ mice causes the pathological accumulation of both $A \beta$ and tau, two proteins that are themselves degraded by the proteosome.

Caspase activation, a key step in apoptosis, occurs in AD and leads to the proteolytic cleavage of several neuronal proteins (Jordan et al., 1997). Recent studies suggest that plaques, tangles, and caspase activation share a common pathway. $\mathrm{A} \beta$ can activate caspases (Harada and Sugimoto, 1999; Ivins et al., 1999; Nakagawa et al., 2000; Troy et al., 2000; Yamakava et al., 2000). Activated caspases can, in turn, cleave tau, the main component of neurofibrillary tangles. Caspase-cleaved tau may initiate or accelerate the development of tangle pathology, as evidenced by recent studies (Cotman et al., 2005; Sorrentino and Bonavita, 2007).

\section{SOMATOSTATIN AND THE MODULATION OF ADENYLYL CYCLASE ACTIVITY IN ALZHEIMER'S DISEASE}

Somatostatin (SRIF), a regulatory peptide with two bioactive forms, SRIF-14 and SRIF-28, is produced in neuroendocrine cells in the brain and periphery and acts on a wide array of tissue targets to modulate neurotransmission, cell secretion and cell proliferation (Reichlin, 1983; Epelbaum et al., 1994; Patel, 1999). SRIF has also been reported to modulate both motor activity and cognition (Gillies, 1997). Somatostatinergic neurons occur in high densities throughout the central nervous system (CNS) and give rise to an extensive network of SRIF-containing fibers and axon terminals in numerous brain regions including the cerebral cortex, hippocampus, 
amygdala, hypothalamus, brainstem and spinal chord (Johansson et al., 1984). SRIF exerts its physiological effects via interaction with a family of five G-protein-coupled receptors, termed SSTR1-SSTR5 (Moller et al., 2003; Olias et al., 2004), with two splice variants of SSTR2 having been identified in mouse and rat, SSTR2A and SSTR2B (Vanetti et al., 1992, Vanetti et al., 1993). SSTRs can couple to multiple cellular effector systems, including adenylyl cyclase (AC), $\mathrm{Ca}^{2+}$ and $\mathrm{K}^{+}$channels, phospholipase A, serine/threonine phosphatases, and tyrosine phosphatases (Panetta et al., 1995; Patel et al., 1995). One SSTR subtype may be linked to more than one effector system, and the actual pattern of SSTR-effector coupling appears to be cell or tissue specific, most likely based on which Gi proteins and effector system are present. Among the different neuropeptides whose levels are significantly altered in patients with Alzheimer's disease (AD), SRIF is reported to be the most consistently reduced, both in brain and cerebrospinal fluid (CSF) (Davies et al., 1980; Beal et al., 1986; Davis et al., 1988; Bissette and Myers, 1992; Nemeroff et al., 1992; Molchan et al., 1993; Bissette et al., 1998; Nilsson et al., 2001).

Recent immunohistochemical analyses of human control and AD brains have revealed a significant reduction $(>70 \%)$ in the number of SRIF-immunoreactive neurons in the AD frontal cortex (Kumar, 2005), which would account for the deficit in SRIF concentration previously reported in this brain area (Davies et al., 1980; Dournaud et al., 1995). In the hippocampus, a substantial early loss of SRIF-immunopositive neurons and SRIF mRNA was detected in a transgenic mouse model of $\mathrm{AD}$, in the absence of changes in other neuronal markers of GABAergic, glutamatergic and cholinergic systems or in the principal cell number (Ramos et al., 2006). Furthermore, a linear correlation between SRIF deficiency and $A \beta$ content was observed. In view of these 
findings, SRIF could constitute an important biomarker to assess the efficacy of potential early AD treatments (Ramos et al., 2006).

On the other hand, continuous intracerebroventricular (i.c.v.) infusion of $\mathrm{A} \beta 1$ 40 or A $\beta 25-35$ for 14 days results in a significant reduction in SRIF-LI content in the rat hippocampus, frontoparietal cortex and temporal cortex (Nag et al., 1999; HervásAguilar at al., 2005; Aguado-Llera et al., 2005; Burgos-Ramos et al., 2007), which parallels that seen in postmortem brains of patients with AD (Davies et al. 1980). These findings suggest that the accumulation of $\mathrm{A} \beta$ peptides contributes, at least partly, to the well-documented deficits in SRIF-LI content throughout the AD brain.

Accumulating evidence indicates that in addition to a SRIF deficiency, abnormalities at the level of the SRIF receptors, which transduce the SRIF signal, are also present in the AD brain. Initial studies by Beal et al. (1985) in the AD post-mortem brain revealed a dramatic reduction of approximately 50\% in the SRIF receptor density, as compared to age-matched control brains, in the frontal cortex (Brodman areas 6, 9 and 10) and temporal cortex (Brodman area 21), regions where the SRIF deficit is also most notable. No changes, however, were detected in the SRIF receptor affinity in any of these cortical areas. The SRIF receptor concentration was unaltered in the cingulate cortex, hippocampus and postcentral gyrus. The correlation between reduced SRIF-LI and reduced SSTRs in the same cortical areas of AD patients could reflect loss of both presynaptic (SRIF) and postsynaptic (SRIFceptiv) neurons in areas which are predisposed to the pathologic process (Beal et al., 1985). In contrast, Withford et al. (1988) found no changes in the SRIF receptor density in AD brain; this discrepancy is most likely attributable to differences in the severity of the cases analyzed.

Recent studies have unraveled the specific SSTR subtypes affected in AD. Initial radioligand binding assays demonstrated a reduction in the maximal binding capacity of 
those SSTRs showing high affinity for SMS201-995 (a SRIF analogue), currently known to be SSTR2, SSTR3 and SSTR5, in the AD frontal and temporal cortex, with preservation of other SRIF receptor subtypes (Krantic et al., 1992). More recently, analysis of SSTR1-SSTR5 protein expression in the AD frontal cortex, using specific rabbit polyclonal antibodies directed against each subtype, revealed a marked reduction in SSTR4- and SSTR5-immunopositive neurons, a modest decrease in SSTR2-like immunoreactivity, and no significant differences in SSTR1-immunoreactive neurons when compared with age-matched controls (Kumar, 2005). In contrast, SSTR3 was markedly increased in the AD cortex. Altogether, these findings showing subtypeselective alterations in SSTR protein expression in AD cortical regions provide an emerging picture of a central role not only of SRIF but of SSTR subtypes in the pathophysiology of AD.

Our group (Burgos-Ramos et al., 2007; Aguado-Llera et al., 2005; HervásAguilar at al., 2005) has found that continuous i.c.v. infusion of A $\beta 25-35$ induces a selective decrease in SSTR2 mRNA and protein levels in the rat temporal cortex, as well as a decrease in SSTR density in the frontoparietal cortex and frontal or parietal cortex alone, exerting no effect in the hippocampus. These results support the hypothesis that $A \beta$ peptides play a pivotal role in the alterations of SSTRs detected in the human $\mathrm{AD}$ brain, as described above.

Since SSTRs couple negatively to AC via inhibitory guanine-nucleotide-binding proteins (Gi proteins), numerous laboratories have focused on elucidating whether these components of the SRIF signalling pathway are altered in human AD brain or in animal models of AD. In earlier studies, Bergström et al. (1991) concluded that impaired SRIF modulation of $\mathrm{AC}$ is not a global phenomenon in $\mathrm{AD}$ brain, and that there are no major disruptions of SSTR-G-protein coupling or of AC catalytic activity in AD (see review 
of Vécsei and Klivényi, 1995). Cowburn et al. (1992) reported a preservation of Giprotein inhibited AC activity in the postmortem brains of patients with AD. Likewise, O'Neill et al. (1994) found that Gi-protein-inhibited AC activity was unaltered in the frontoparietal cortex of AD patients, whereas Kato et al. (1991) reported no differences in the relative abundance of Gia2 in the $\mathrm{AD}$ temporal cortex as compared with control values. In contrast, in the AD hippocampus, Ohm et al. (1991) showed reduced forskolin (FK)-stimulated AC activity, suggesting a loss of $\mathrm{AC}$ enzyme units. In addition, a recent study by García-Jiménez et al. (2003) provided evidence of a significant decline in Gia levels in this brain region as well as in the entorhinal cortex, which was parallel to the extent of AD pathology.

Our research group recently found that the A 325 -35-induced decline of SSTR2 expression in the rat temporal cortex, mentioned previously, was accompanied by a decrease in SRIF-mediated inhibition of FK-stimulated AC activity, with no alterations

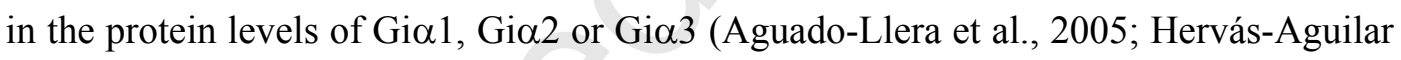
at al., 2005; Burgos-Ramos et al., 2007). No changes were detected in either basal or FK-stimulated AC activity, suggesting that the decreased sensitivity of the enzyme to SRIF inhibition was not due to an alteration in the AC catalytic subunit but rather to the decrease in the SRIF receptors. Interestingly, in the rat hippocampus, where the SRIF receptors are fairly well preserved, A $\beta 25-35$ treatment led to a decrease in both basal and FK-stimulated AC activity and reduced the inhibitory effect of SRIF on both activities as well (Burgos-Ramos et al., 2007). Further analyses of brain-specific AC isoforms revealed a selective decrease in the protein levels of AC I, an increase in those of $\mathrm{AC} \mathrm{V} / \mathrm{VI}$, with no changes in $\mathrm{AC}$ VIII protein expression. Hence, the decrease in $\mathrm{AC}$ I most probably accounts for the observed decrease in AC activity. These findings are partially concordant with studies by Yamamoto et al. $(1997,2000)$ who showed a 
significant loss of AC I in the AD hippocampus and parietal cortex. It is worth noting that $\mathrm{AC}$ I has been postulated to play a pivotal role in learning and memory (Sunahara and Taussig, 2002).

\section{SOMATOSTATIN, COGNITIVE FUNCTION AND AMYLOID $\beta$ - PEPTIDE}

Among the varied functions in which the somatostatinergic system is engaged, the regulation of cognitive processes such as learning and memory (Vécsei et al., 1984; Cacabelos et al., 1988) merits special attention. Dournaud and colleagues (1995) found that SRIF content declined significantly with cognitive deficits in the frontal cortex of post-mortem $\mathrm{AD}$ brain. On the other hand, potent amnesic properties have been reported for A $325-35$ (Olariu et al., 2001; Yamaguchi and Kawashima, 2001). Hence, the A $\beta 25-$ 35-induced decrease in rat brain SRIF-LI and in SSTR2 protein expression described by our group might be related to the decreased cognitive behaviour reported in A $\beta$-treated rats (Stepanichev, 2000; Olariu et al., 2001; Yamaguchi and Kawashima, 2001) and might partly explain the cognitive impairment characteristic of $\mathrm{AD}$ patients. Notwithstanding, the possibility that the impairment of cognitive function associated with A 25 -35 administration may be due, at least in part, to damage in some other neuronal system cannot be ruled out.

\section{SOMATOSTATIN, NEPRILYSIN AND AMYLOID $\beta$-PEPTIDE}

According to the amyloid hypothesis, accumulation of $A \beta$ in the brain is the primary influence driving AD pathogenesis (Hardy and Selkoe, 2002). The levels of A $\beta$ in the brain represent a dynamic equilibrium state as a result of biosynthesis from APP by $\beta$ - and $\gamma$-secretases, degradation by $A \beta$-degrading enzymes, subsequent oligomerization, and deposition into senile plaques (Turner and Nalivaeva, 2007). 
Several zinc metallopeptidases have been recently identified as A $\beta$-degrading enzymes; these include neprilysin (Iwata et al., 2000; Iwata et al., 2001), endothelin-converting enzyme (Eckman et al., 2001), and insulin-degrading enzyme (Farris et al., 2003). Neprilysin, however, seems to play the the major role in $A \beta$ catabolism in the brain in vivo. Neprilysin was found to degrade both $A \beta 1-40$ and $A \beta 1-42$ in vivo most rapidly and efficiently (Shirotani et al., 2001). Furthermore, in neprilysin-knockout mice, a significant elevation in the levels of $A \beta 1-40$ and $A \beta 1-42$ was detected, which was greater than that seen in other $A \beta$-degrading enzyme knockout mice (Iwata et al., 2001). These findings might be clinically relevant given the fact that neprilysin expression in the brain decreases during aging and in the early stages of $\mathrm{AD}$ progression (Yasojima et al, 2001; Iwata et al, 2002), whereas elevated neprilysin activity reduces the accumulation of both soluble and fibrillar A $\beta$ in APP transgenic mice (Leissring et al, 2003; Iwata et al, 2004).

There is now compelling evidence of a very close relationship between SRIF, neprilysin and A $\beta$. First, both neprilysin expression and SRIF content in the brain decrease during aging. Secondly, in primary cortical neurons, Saito et al. (2005) have demonstrated that SRIF significantly increases neuronal neprilysin activity and decreases A $\beta 1-42$ levels in the culture medium. This effect is clearly mediated via SRIF receptors since both an SSTR antagonist (BIM23056) and a Gi inhibitor (pertussis toxin) inhibit neprilysin activation. Thirdly, in the hippocampus of SRIF-precursor protein-knockout mice, neprilysin activity was found to be significantly lower than that in wild-type mice (Saito et al., 2005). In addition, a 50\% increase in A $\beta 1-42$ levels was detected, there being no alterations in APP metabolism. Altogether, these results indicate that the aging-induced downregulation of SRIF expression may be a trigger for $\mathrm{A} \beta$ accumulation in the brain, via reduction of neprilysin action (Hama and Saido, 
2005) (Figure 1), thus leading to late-onset sporadic AD. These findings also suggest that SSTRs, possibly SSTR2 and SSTR4, which are the most abundant SSTRs in neocortex and hippocampus (Möller et al., 2003), may be pharmacological-target candidates for prevention and treatment of AD.

\section{PROTECTIVE EFFECTS OF IGF-I ON THE SOMATOSTATINERGIC

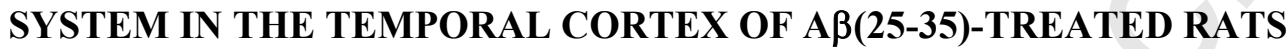

The decrease in SRIF-LI concentration detected in the rat temporal cortex after chronic A $\beta 25-35$ infusion is prevented by exogenous IGF-I treatment (Figure 2) (Aguado-Llera et al., 2005). Our results demonstrate that peripheral administration of IGF-I increases cortical levels of this growth factor, as has been previously reported in other brain areas (Fernández et al., 1998; Carro et al., 2000). Indeed, peripheral IGF-I crosses the blood-brain barrier into the brain parenchyma (Reinhardt and Bondy 1994). The mechanism by which IGF-I prevents the decline in SRIF-LI levels in the rat temporal cortex remains unknown, but might be related to a direct effect of this growth factor on SRIF cell survival. Indeed, subcutaneous infusion of IGF-I reduces A $\beta$ levels in the brain (Carro et al., 2002) and protects neurons from A $\beta$-induced cell death (Doré et al., 1997). We have previously shown that SRIF- and SSTR2-immunopositive cells colocalize with TUNEL labeling, which identifies the cell types undergoing apoptosis, in sections of the temporal cortex from A $325-35$-treated rats (Aguado-Llera et al., 2006). In addition, our results show that $A \beta 25-35$ reduces the activated form of Akt, an intracellular signaling pathway that is down-regulated in $\mathrm{AD}$ patients with mutations of the $A \beta$ precursor protein (Ryder et al., 2004). Interestingly, IGF-I normalized phosphorylated-Akt (p-Akt) protein levels in the A $\beta 25-35$-treated-rats, and it has been previously demonstrated that IGF-I protects against A $\beta$-induced cell death through 
activation of Akt (Dudek et al., 1997). The lack of changes in the MAPK pathway indicates that the survival properties of IGF-I are most likely not mediated via this intracellular mechanism (Zheng and Quirion 2004). Another molecular mechanism by which IGF-I could suppress A $\beta$ toxicity has been recently reported by Wei et al. (2002). In their study, A $\beta 25-35$ caused an increase in c-Jun N-terminal kinase (JNK), highly activated in response to a variety of stress signals, and IGF-I is known to protect against A $\beta$-induced cell death by blocking JNK activation. Alternatively, IGF-I could increase SRIF mRNA levels in these neurons, as it does in other tissues (Ghigo et al., 1997). In our study, IGF-I infusion also normalised the SRIF receptor density, via an increase in SSTR2 protein levels. Kimura et al. (2001) have demonstrated that within the 5' untranslated region of the SSTR2 gene, two introns separate three transcriptional units with distinct promoters, making it unique among all SSTR genes regarding its transcriptional regulation. The second SSTR2 promoter is important for expression of the gene in tissues such as the brain or pituitary and contains cis-acting regulatory elements involved in the transcriptional response to elevated cAMP levels and glucocorticoids. IGF-I has been reported to increase phosphorylation of the cAMP response element binding protein (CREB) (Yamada et al., 2001), which might thus enhance SSTR2 gene expression (Kraus et al., 2000).

Altogether, the findings reviewed here may contribute to a better understanding of the implication of SRIF in this complex neurological disorder and may eventually help in the development of new pharmacological strategies for the effective treatment of AD. 


\section{REFERENCES}

Aguado-Llera, D., Arilla-Ferreiro, E., Campos-Barros, A., Puebla-Jiménez, L., Barrios, V., 2005. Protective effects of insulin-like growth factor-I on the somatostatinergic system in the temporal cortex of $\beta$-amyloid-treated rats. J. Neurochem. 92, 607-615.

Aguado-Llera, D., Arilla-Ferreiro, Chowen J.A., Argente, J., Puebla-Jiménez, L., Frago, L.M., Barrios, V., 2006. 17 $\beta$-estradiol protects depletion of rat temporal cortex somatostatinergic system by beta-amyloid. Neurobiol. Aging (doi 10.1016/j.neurobiolaging.2006.06.009).

Almeida, C.G., Takahashi, R.H., Gouras, G.K., 2006. Beta-amyloid accumulation impairs multivesicular body sorting by inhibiting the ubiquitin-proteasome system. J. Neurosci. 26, 4277-4288.

Anandatheerthavarada, H.K., Biswas, G., Robin, M.A., Avadhani, N.G., 2003. Mitochondrial targeting and a novel transmembrane arrest of Alzheimer's amyloid precursor protein impairs mitochondrial function in neuronal cells. J. Cell. Biol. $161,41-54$.

Beal, M.F., Mazurek, M.F., Tran, V.T., Chattha, G., Bird, E.D., Martin, J.B., 1985. Reduced numbers of somatostatin receptors in the cerebral cortex in Alzheimer's disease. Science 229, 289-291.

Beal, M.F., Mazurek, M.F., Svendsen, C.N., Bird, E.D., Martin, J.B., 1986. Widespread reduction of somatostatin-like immunoreactivity in the cerebral cortex in Alzheimer's disease. Ann. Neurol. 20, 489-495. 
Bergström, L., Garlind, A., Nilsson, L., Alafuzoff, I., Fowler, C.J., Winblad, B., Cowburn, R.F., 1991. Regional distribution of somatostatin receptor binding and modulation of adenylyl cyclase activity in Alzheimer's disease brain. J. Neurol. Sci. 105, 225-233.

Bissette, G., Myers, B., 1992. Somatostatin in Alzheimer's disease and depression. Life Sci. $51,1389-1410$.

Bissette, G., Cook, L., Smith, W., Dole, K.C., Crain, B., Nemeroff, C.B., 1998. Regional neuropeptide pathology in Alzheimer's disease: corticotropin-releasing factor and somatostatin. J. Alzheimers Dis. 1, 91-105.

Bossy-Wetzel, E., Schwarzenbacher, R., Lipton, S.A., 2004. Molecular pathways to neurodegeneration. Nat. Med. 10, S2-9.

Braak, H., Braak, E., 1991. Neuropathological stageing of Alzheimer-related changes. Acta Neuropathol. 82, 239-259.

Burgos-Ramos, E., Hervás-Aguilar, A., Puebla-Jiménez, L., Boyano-Adánez, M.C., Arilla-Ferreiro, E., 2007. Chronic but not acute intracerebroventricular administration of amyloid $\beta$-peptide (25-35) decreases somatostatin content, adenylate cyclase activity, somatostatin-induced inhibition of adenylate cyclase activity and adenylate cyclase I levels in the rat hippocampus. J. Neurosci. Res. $85,433-442$.

Bush, A.I., Multhaup, G., Moir, R.D., Williamson, T.G., Small, D.H., Rumble, B., Pollwein, P., Beyreuther, K., Masters, CL., 1993. A novel zinc(II) binding site modulates the function of the beta A4 amyloid protein precursor of Alzheimer's disease. J. Biol. Chem. 268, 16109-16112.

Bush, A.I., 2003. Copper, zinc, and the metallobiology of Alzheimer disease. Alzheimer Dis. Assoc. Disord. 17,147-150. 
Cacabelos, R., Niigawa, H., Rodríguez-Arnao, M.D., Gomez-Pan, A., Nishimura, T., 1998. Influence of somatostatin and growth hormone-releasing factor on behaviour. Horm. Res. 29, 129-132.

Carro, E., Núñez, A., Busiguina, S., Torres-Alemán, I., 2000. Circulating insulin-like growth factor I mediates effects of exercise on the brain. J. Neurosci. 20, 29262933.

Carro, E., Trejo, J.L., Gómez-Isla, T., LeRoith, D., Torres-Alemán, I., 2002. Serum insulin-like growth factor I regulates brain amyloid-beta levels. Nature Med. 8, $1390-1397$.

Casley, C.S., Land, J.M., Sharpe, M.A., Clark, J.B., Duchen, M.R., Canevari, L., 2002. Beta-amyloid fragment 25-35 causes mitochondrial dysfunction in primary cortical neurons. Neurobiol. Dis. 10, 258-267.

Cotman, C.W., Poon, W.W., Rissman, R.A., Blurton-Jones, M., 2005. The role of caspase cleavage of tau in Alzheimer disease neuropathology. J. Neuropathol. Exp. Neurol. 64,104-112.

Cowburn, R.F., O'Neill, C., Ravid, R., Alafuzoff, I., Winbland, B., Fowler, C.J., 1992. Adenylate cyclase activity in postmortem human brain: evidence of altered $G$ protein mediation in Alzheimer's disease. J. Neurochem. 58, 1409-1419.

Davis, K.L., Davidson, M., Yang, R.K., Davis, B.M., Siever, L.J., Mohs, R.C., Ryan, T., Coccaro, E., Bierer, L., Targum, S.D., 1988. CSF somatostatin in Alzheimer's disease, depressed patients, and control subjects. Biol. Psychiatry 24, 710-712.

Davies, P., Katzman, R., Terry, RD., 1980. Reduced somatostatin-like immunoreactivity in cerebral cortex from cases of Alzheimer disease and Alzheimer senile dementia. Nature 288, 279-280. 
Dong, J., Atwood, C.S., Anderson, V.E., Siedlak, S.L., Smith, M.A., Perry, G., Carey, P.R., 2003. Metal binding and oxidation of amyloid-beta within isolated senile plaque cores: Raman microscopic evidence. Biochemistry 42, 2768-2773.

Doré, S., Kar, S., Quirion, R., 1997. Insulin-like growth factor I protects and rescues hippocampal neurons against $\beta$-amyloid and human amylin-induced toxicity. Proc. Natl. Acad. Sci. USA 94, 4772-4777.

Dournaud, P., Dalaere, P., Hauw, J.J., Epelbaum, J., 1995. Differential correlation between neurochemical deficits, neuropathology and cognitive status in Alzheimer's disease. Neurobiol. Aging 16, 817-823.

Dournaud, P., Jazat-Poindessous, F., Slama, A., Lamour, Y., Epelbaum, J., 1996. Correlations between water maze performance and cortical somatostatin mRNA and high-affinity binding sites during ageing in rats. Eur. J. Pharmacol. 8, 476485.

Dudek, H., Datta, S.R., Franke, T.F., Birnbaum, M.J., Yao, R., Cooper, G.M., Segal, R.A., Kaplan, D.R., Greenberg, M.E., 1997. Regulation of neuronal survival by the serine-threonine protein kinase Akt. Science 275, 661-665.

Eckman, E.A., Reed, D.K., Eckman, C.B., 2001. Degradation of the Alzheimer's amyloid $\beta$ peptide by endothelin-converting enzyme. J. Biol. Chem. 276, 2454024548.

Epelbaum, J., Dournaud, P., Fodor, M., Viollet, C., 1994. The neurobiology of somatostatin. Crit Rev Neurobiol. 8, 25-44. 
Farris, W., Mansourian, S., Chang, Y., Lindsley, L., Eckman, E.A., Frosch, M.P., Eckman, C.B., Tanzi, R.E., Selkoe, D.J., Guenette, S., 2003. Insulin-degrading enzyme regulates the levels of insulin, amyloid $\beta$-protein, and the $\beta$-amyloid precursor protein intracellular domain in vivo. Proc. Natl. Acad. Sci. USA 100, $4162-4167$.

García-Jiménez, A., Fastbom, J., Ohm, T.G., Cowburn, R.F., 2003. G-protein alphasubunit levels in hippocampus and entorhinal cortex of brains staged for Alzheimer's disease neurofibrillary and amyloid pathologies. Neuroreport 14, $1523-1527$.

Ghigo, M.C., Torsello, A., Grilli, R., Luoni, M., Guidi, M., Cella, S.G., Locatelli, V., Muller, E.E., 1997. Effects of GH and IGF-I administration on GHRH and somatostatin mRNA levels: I. A study on ad libitum fed and starved adult male rats. J. Endocrinol. Invest. 20, 144-150.

Gillies, G., 1997. Somatostatin: the neuroendocrine story. Trends. Pharmacol. Sci. 18, $87-95$.

Gregori, L., Fuchs, C., Figueiredo-Pereira, M.E., Van Nostrand, W.E., Goldgaber, D., 1995. Amyloid beta-protein inhibits ubiquitin-dependent protein degradation in vitro. J. Biol. Chem. 270, 19702-19708.

Hama, E., Saido, T.C., 2005. Etiology of sporadic Alzheimer's disease: somatostatin, neprilysin, and amyloid beta peptide. Med. Hypotheses 65, 498-500.

Harada, J.,Sugimoto, M., 1999. Activation of caspase-3 in $\beta$-amyloid-induced apoptosis of cultured rat cortical neurons. Brain Res. 842,311-323.

Hardy, J.A., Higgins, G.A., 1992. Alzheimer's disease: the amyloid cascade hypothesis. Science 256, 184-185. 
Hardy, J.A., Selkoe, D.J., 2002. The amyloid hypothesis of Alzheimer's disease: progress and problems on the road to therapeutics. Science 297, 353-356.

Hernández, F., Díaz-Hernández, M., Ávila, J., Lucas, J.J., 2004. Testing the ubiquitinproteasome hypothesis of neurodegeneration in vivo. Trends Neurosci. 27, 66-69.

Hervás-Aguilar, A., Puebla-Jiménez, L., Burgos-Ramos, E., Aguado-Llera, D., ArillaFerreiro, E., 2005. Effects of single and continuous administration of amyloid $\beta$ peptide (25-35) on adenylyl cyclase activity and the somatostatinergic system in the rat frontal and parietal cortex. Neuroscience 135, 181-190.

Hirai, K., Aliev, G., Nunomura, A., Fujioka, H., Russell, R.L., Atwood, C.S., Johnson, A.B., Kress, Y., Vinters, H.V., Tabaton, M., Shimohama, S., Cash, A.D., Siedlak, S.L., Harris, P.L., Jones, P.K., Petersen, R.B., Perry, G., Smith, M.A., 2001. Mitochondrial abnormalities in Alzheimer's disease. J. Neurosci. 21, 3017-3023.

Hsiao, K., Chapman, P., Nilsen, S., Eckman, C., Harigaya, Y., Younkin, S., Yang, F., Cole, G., 1996. Correlative memory deficits, Abeta elevation, and amyloid plaques in transgenic mice. Science $274,99-102$.

Iwata, N., Tsubuki, S., Takaki, Y., Watanabe, K., Sekiguchi, M., Hosoki, E., Kawashima-Morishima, M., Lee, H.J., Hama, E., Sekine-Aizawa, Y., Saido, T.C., 2000. Identification of the major $A \beta_{1-42}$-degrading catabolic pathway in brain parenchyma: suppression leads to biochemical and pathological deposition. Nat.Med. 6, 143-150.

Iwata, N., Tsubuki, S., Takaki, Y., Shirotani, K., Lu, B., Gerard, N.P., Gerard, C., Hama, E., Lee, H.J., Saido, T.C., 2001. Metabolic regulation of brain A $\beta$ by neprilysin. Science 292, 1550-1552. 
Iwata, N., Takaki, Y., Fukami, S., Tsubuki, S., Saido, T.C., 2002. Region-specific reduction of $\mathrm{A} \beta$-degrading endopeptidase, neprilysin, in mouse hippocampus upon aging. J. Neurosci. Res. 70, 493-500.

Iwata, N., Mizukami, H., Shirotani, K., Takaki, Y., Muramatsu, S., Lu, B., Gerard, N.P., Gerard, C., Ozawa, K., Saido, T.C., 2004. Presynaptic localization of neprilysin contributes to efficient clearance of amyloid- $\beta$ peptide in mouse brain. J. Neurosci. 24, 991-998.

Ivins, K.J., Thornton, P.L., Rhon, T.T., Cotman, C.W., 1999. Neuronal apoptosis induced by $\beta$-amyloid is mediated by caspase- 8 . Neurobiol. Dis. $6,440-449$.

Johansson, O., Hoekfelt, T., Elde, R.P., 1984. Immunochemical distribution of somatostatin-like immunoreactivity in the central nervous system of the adult rat. Neuroscience. 13, 265-339.

Jordán, J., Galindo, M.F., Miller, R.J., 1997. Role of calpain- and interleukin-1 beta converting enzyme-like proteases in the beta-amyloid-induced death of rat hippocampal neurons in culture. J. Neurochem. 68, 1612-1621.

Kamal, A., Almenar-Queralt, A., LeBlanc, J.F., Roberts, E.A., Goldstein, L.S., 2001. Kinesin-mediated axonal transport of a membrane compartment containing $\beta$ secretase and presenilin-1 requires APP. Nature 414, 646-648.

Kato, K., Kurobe, N., Suzuki, F., Marishita, R., Asano, T., Imagaki, T., 1991. Concentrations of several proteins characteristic of nervous tissue in cerebral cortex of patients with Alzheimer's disease. J. Mol. Neurosci. 3, 95-99.

Kimura, N., Tomizawa, S., Arai, K.N., Osamura, R.Y., Kimura. N., 2001. Characterization of 5'-flanking region of rat somatostatin receptor sst2 gene: transcriptional regulatory elements and activation by Pitx1 and estrogen. Endocrinology 142,1427-1441. 
Krantic, S., Robitaille, J., Quirion, R., 1992. Deficits in the somatostatin SS1 receptor sub-type in frontal and temporal cortices in Alzheimer's disease. Brain Res. 573, 299-304.

Kraus, J., Wöltje, M., Schönwetter, N., Höllt, V., 2000. Gene structure and regulation of the somatostatin receptor type 2. J. Physiol. 94, 199-204.

Kubo, T., Nishimura, S., Kumagae, Y., Kaneko, I., 2002. In vivo conversion of racemized $\beta$-amyloid ([D-Ser $\left.\left.{ }^{26}\right] \mathrm{A} \beta 1-40\right)$ to truncated an toxic fragments ([D$\mathrm{Ser}^{26} \mathrm{~A} \beta 25-35 / 40$ ) and fragment presence in the brains of Alzheimer's patients. J. Neurosci. Res. 70, 474-483.

Kumar, U., 2005. Expression of somatostatin receptor subtypes (SSTR1-5) in Alzheimer's disease brain: an immunohistochemical analysis. Neuroscience 134, $525-538$.

Leissring, M.A., Farris, W., Chang, A.Y., Walsh, D.M., Wu, X., Sun, X., Frosch, M.P., Selkoe, D.J., 2003. Enhanced proteolysis of $\beta$-amyloid in APP transgenic mice prevents plaque formation, secondary pathology, and premature death. Neuron 40, 1087-1093.

Lipton, S.A., 2004. Concepts: turning down but not off- Neuroprotection requires a paradigm shift in drug development. Nature 428, 473-475.

Lovell, M.A., Robertson, J.D., Teesdale, W.J., Campbell, J.L., Markesbery, W.R., 1998. Copper, iron and zinc in Alzheimer's disease senile plaques. J. Neurol. Sci. 158, 47-52. 
Lustbader, J.W., Cirilli, M., Lin, C., Xu, H.W., Takuma, K., Wang, N., Caspersen, C.,

Chen, X., Pollak, S., Chaney, M., Trinchese, F., Liu, S., Gunn-Moore, F., Lue, L.F., Walker, D.G., Kuppusamy, P., Zewier, Z.L., Arancio, O., Stern, D., Yan, S.S., Wu, H., 2004. ABAD directly links Abeta to mitochondrial toxicity in Alzheimer's disease. Science. 304, 448-452.

Molchan, S.E., Hill, J.L., Martínez, R.A., Lawlor, B.A., Mellow, A.M., Rubinow, D.R., Bissette, G., Nemeroff, C.B., Sunderland, T., 1993. CSF somatostatin in Alzheimer's disease and major depression: relationship to hypothalamic-pituitaryadrenal axis and clinical measures. Psychoneuroendocrinology 18, 509-519.

Moller, L.N., Stidsen, C.E., Hartmann, B., Holst, J.J., 2003. Somatostatin receptors. Biochim. Biophys. Acta 1616, 1-84.

Moore, D.J., Dawson, V.L., Dawson, T.M., 2003. Role for the ubiquitin-proteasome in Parkinson's disease and othe neurodegenerative brain amyloidoses. Neuromolecular Med. 4, 95-108.

Nag, S., Yee, B.K.,Tang, F., 1999. Reduction in somatostatin and substance P levels and choline acetyltransferase activity in the cortex and choline hippocampus of the rat after chronic intracerebroventricular infusion of $\beta$-amyloid (1-40). Brain Res. Bull. 50, 251-262.

Nakagawa, T., Zhu, H., Morishima, N., Li, E., Xu, J., Yankner, B.A., Yuan, J., 2000. Caspase-12 mediates endoplasmatic reticulum-specific apoptosis and cytotoxicity by amyloid- $\beta$. Nature 403, 91-103.

Nemeroff, C.B., Knight, D.L., Bissette, G., 1992. Somatostatin: a neuropeptide system pathologically altered in Alzheimer's disease and depression. Clin. Neuropharmacol. 15, 311A-312A. 
Nilsson, C.L., Brinkmalm, A., Minthon, L., Blennow, K., Ekman, R., 2001. Processing of neuropeptide $\mathrm{Y}$, galanin, and somatostatin in the cerebrospinal fluid of patients with Alzheimer's disease and frontotemporal dementia. Peptides 22, 2105-2112.

Oh, S., Hong, H.S., Hwang, E., Sim, H.J., Lee, W., Shin, S.J., Mook-Jung, I., 2005. Amyloid peptide attenuates the proteasome activity in neuronal cells. Mech. Ageing Dev. 126,1292-1299.

Ohm, T.G., Bohl, J., Lemmer, B., 1991. Reduced basal and stimulated (isoprenaline, $\mathrm{Gpp}(\mathrm{NH}) \mathrm{p}$, forskolin) adenylate cyclase activity in Alzheimer's disease correlated with histopathological changes. Brain Res. 540, 229-236.

Olariu, A., Tran, M.H., Yamada, K., Mizuno, M., Hefco, V., Nabeshima, T., 2001. Memory deficits and increased emotionality induced by $\beta$-amyloid (25-35) are correlated with the reduced acetylcholine release and altered phorbol dibutyrate binding in the hippocampus. J. Neural. Transm. 108, 1065-1079.

Olias, G., Viollet, C., Kusserow, H., Epelbaum, J., Meyerhof, W., 2004. Regulation and function of somatostatin receptors. J Neurochem. 89, 1057-1091.

O’Neill, C., Wiehager, B., Fowler, C.J., Ravid, R., Winblad, B., Cowburn, R.F., 1994. Regionally selective alterations in G protein subunit levels in the Alzheimer's disease brain. Brain Res. 636, 193-201.

Orlowski, R.Z., 1999. The role of ubiquitin-proteasome pathway in apoptosis. Cell. Death Differ. 6, 303-313.

Panetta, R., Patel, Y.C., 1995. Expression of mRNA for all five human somatostatin receptors (hSSTR1-5) in pituitary tumors. Life Sci. 56, 333-342.

Patel, Y.C., 1999 Somatostatin and its receptor family. Front. Neuroendocrinol. 20, 157198. 
Patel, Y.C., Greenwood, M.T., Panetta, R., Demchyshyn, L., Niznik, H., Srikant, C.B., 1995. The somatostatin receptor family. Life. Sci. 57, 1249-1265.

Pigino, G., Morfini, G., Pelsman, A., Mattsonm M.P., Brady, S.T., Busciglio, J., 2003. Alzheimer's presenilin 1 mutations impair kinesin-based axonal transport. J Neurosci.. 23, 4499-4508.

Pike, C.J., Brudick, D., Walencevicz, A.J., Glab, C.G., Cotman, C.W., 1993. Neurodegeneration induced by $\beta$-amyloid peptides in vitro: the role of peptide assembly state. J. Neurosci. 13, 1676-1687.

Ramos, B., Baglietto-Vargas, D., del Rio, J.C., Moreno-Gonzalez, I., Santa-Maria, C., Jiménez, S., Caballero, C., Lopez-Tellez, J.F., Khan, Z.U., Ruano, D., Gutierrez, A., Vitorica, J., 2006. Early neuropathology of somatostatin/NPY GABAergic cells in the hippocampus of a PS1 $\times$ APP transgenic model of Alzheimer's disease. Neurobiol. Aging 27, 1658-1672.

Reichlin, S., 1983. Somatostatin. N. Engl. J. Med. 309, 1495-1501.

Reinhardt, R.R., Bondy, C.A., 1994. Insulin-like growth factors cross the blood-brain barrier. Endocrinology 135, 1753-1761.

Ryder, J., Su, Y., Ni, B., 2004. Akt/GSK3beta serine/threonine kinases: evidence for a signalling pathway mediated by familial Alzheimer's disease mutations. Cell Signal. 16, 187-200.

Saito, T., Iwata, N., Tsubuki, S., Takaki, Y., Takano, J., Huang, S.M., Suemoto, T., Higuchi, M., Saido, T.C., 2005. Somatostatin regulates brain amyloid $\beta$ peptide $\mathrm{A} \beta_{42}$ through modulation of proteolytic degradation. Nat. Med. 11, 434-439.

Sambamurti, K., Greig, N. H., Lahiri, D.K., 2002. Advances in the cellular and molecular biology of the beta-amyloid protein in Alzheimer's disease. Neuromol. Med. 1, 1-31. 
Scheuner, D., Eckman, C., Jensen, M., Song, X., Citron, M., Suzuki, N., Bird, T.D., Hardy, J., Hutton, M., Kukull, W., Larson, E., Levy-Lahad, E., Viitanen, M., Peskind, E., Poorkaj, P., Schellenberg, G., Tanzi, R., Wasco, W., Lannfelt, L., Selkoe, D., Younkin, S., 1996. Secreted amyloid $\beta$-protein similar to that in the senile plaques of Alzheimer's disease is increased in vivo by the presenilin 1 and 2 and APP mutations linked to familial Alzheimer's disease. Nat. Med. 2, 864-870.

Selkoe, D.J., 2002. Alzheimer's disease is a synaptic failure. Science 298, 789-791.

Shirotani, K., Tsubuki, S., Iwata, N., Takaki, Y., Harigaya, W., Maruyama, K., KiryuSeo, S., Kiyama, H., Iwata, H., Tomita, T., Iwatsubo, T., Saido, T.C., 2001. Neprilysin degrades both amyloid b peptides 1-40 and 1-42 most rapidly and efficiently among thiorphan- and phosphoramidon-sensitive endopeptidases. J. Biol. Chem. 276, 21895-21901.

Schulz, S., Handel, M., Schreff, M., Schmidt, H., Hollt, V., 2000. Localization of five somatostatin receptors in the rat central nervous system using subtype-specific antibodies. J. Physiol. Paris. 94, 259-264.

Selkoe, D.J., 1996. Amyloid $\beta$-protein and the genetics of Alzheimer's disease. J. Biol. Chem. 271, 18295-18298.

Selkoe, D.J., 2001. Alzheimer's disease: genes, proteins, and therapy. Physiol. Rev. 81, 741-766.

Sorrentino, G., Bonavita, V., 2007. Neurodegenerative and Alzheimer's disease: The lesson from tautopathies. Neurol. Sci. 28, 63-71.

Stepanichev, M.Y., Onufriev, M.V., Mitrokhina, O.S., Moiseeva, Y.V., Lazareva, N.A., Victorov, I.V., 2000. Neurochemical, behavioural and neuromorphological effects of central administration of $\beta$-amyloid peptide (25-35) in rat. Neurochemistry 17 , 291-306. 
Stewart, W.F., Kawas, C., Corrada, M., Metter, E.J., 1997. Risk of Alzheimer's disease and duration of NSAID use. Neurobiology 48, 626-632.

Sunahara, R.K., Taussig, R., 2002. Isoforms of mammalian adenylate cyclase: multiplicities of signaling. Mol. Intervent. 2, 168-184.

Troy, C.M., Rabacchi, S.A., Friedman, W.J., Frappier, T.F., Brown, K, helanski, M.L. 2000. Caspase-2 mediates neuronal cell death induced by $\beta$-amyloid. J. Neurosci. 20,1386-1392.

Tseng, B.P., Green, K.N., Chan, J.L., Blurton-Jones, M., LaFerla, F.M., 2007.A $\beta$ inhibits the proteasome and enhances amyloid and tau accumulation. Neurobiol. Aging (in press).

Turner, A.J., Nalivaeva, N.N., 2007. New insights into the roles of metalloproteinases in neurodegeneration and neuroprotection. Int. Rev. Neurobiol. 82, 113-135.

Vanetti, M., Kouba, M., Wang, X., Vogt, G., Hollt, V., 1992. Cloning and expression of a novel mouse somatostatin receptor (SSTR2B). FEBS Lett. 311, 290-294.

Vanetti, M., Vogt, G., Hollt, V., 1993. The two isoforms of the mouse somatostatin receptor (mSSTR2A and mSSTR2B) differ in coupling efficiency to adenylate cyclase and in agonist-induced receptor desensitization. FEBS Lett. 331, 260-266.

Vécsei, L., Bollok, I., Telegdy, G., 1984. Phenoxybenzamine antagonizes somatostatininduced anti-amnesia in rats. Eur. J. Pharmacol. 99, 325-328.

Vécsei, L., Klivenyi, P., 1995. Somatostatin and Alzheimer's disease. Arch. Gerontol. Geriat. 21, 35-41.

Weggen, S., Rogers, M., Eriksen, J., 2007. NSAIDs: small molecules for prevention of Alzheimer's disease or precursors for future drug development?.Trends Pharmacol. Sci. 28,536-543. 
Wei, W., Wang, X, Kusiak, J.W., 2002. Signaling events in amyloid beta-peptideinduced neuronal death and insulin-like growth factor I protection. J. Biol. Chem. 277, 17649-17656.

Weiner, M.F., Svetlik, D., Risser, R.C., 1997. What depressive symptoms are reported in Alzheimer's patients?. Int. J. Geriatr. Psychiatry 12, 648-652.

Yamada, M., Tanabe, K., Wada, K., Shimoke, K., Ishikawa, Y., Ikeuchi, T., Koizumi, S., Hatanaka, H., 2001. Differences in survival-promoting effects and intracellular signaling properties of BDNF and IGF-I in cultured cerebral cortical neurons. J. Neurochem. 78, 940-951.

Yamaguchi, Y., Kawashima, S., 2001. Effects of amyloid- $\beta-(25-35)$ on passive avoidance, radial-arm maze learning and choline acetyltransferase activity in the rat. Eur. J. Pharmacol. 412, 265-272.

Yamakawa, H., Ito, Y., Naganawa, T., Banno, Y., Nakashima, S., Yoshimura, S., Sawada, M., Nishimura, Y., Nozawa, Y.,Sakai, N., 2000. Activation of caspase-9 and -3 during $\mathrm{H}_{2} \mathrm{O}_{2}$-induced apoptosis of $\mathrm{PC} 12$ cells independent of ceramide formation. Neurol. Res. 22,556-564.

Yamamoto, M., Ozawa, H., Saito, T., Hatta, S., Riederer, P., Takahata, N., 1997. $\mathrm{Ca} 2+/ \mathrm{CaM}$-sensitive adenylate cyclase activity is decreased in the Alzheimer's brain: possible relation to type I adenylate cyclase. J. Neural. Transm. 104, 721732.

Yamamoto, M., Gotz, M.E., Ozawa, H., Luckhaus, C., Saito, T., Rosler, M., Riederer, P., 2000. Hippocampal level of neural specific adenylate cyclase type I is decreased in Alzheimer's disease. Biochim. Biophys. Acta 1535, 60-68. 
Yasojima, K., Akiyama, H., McGeer, E.G., McGeer, P.L., 2001. Reduced neprilysin in high plaque areas of Alzheimer brain: a possible relationship to deficient degradation of beta-amyloid peptide. Neurosci. Lett. 297, 97-100.

Zheng, W.H., Quirion, R., 2004. Comparative signaling pathways of insulin-like growth factor-1 and brain-derived neurotrophic factor in hippocampal neurons and the role of the PI3 kinase pathway in cell survival. J. Neurochem. 89, 844-852. 


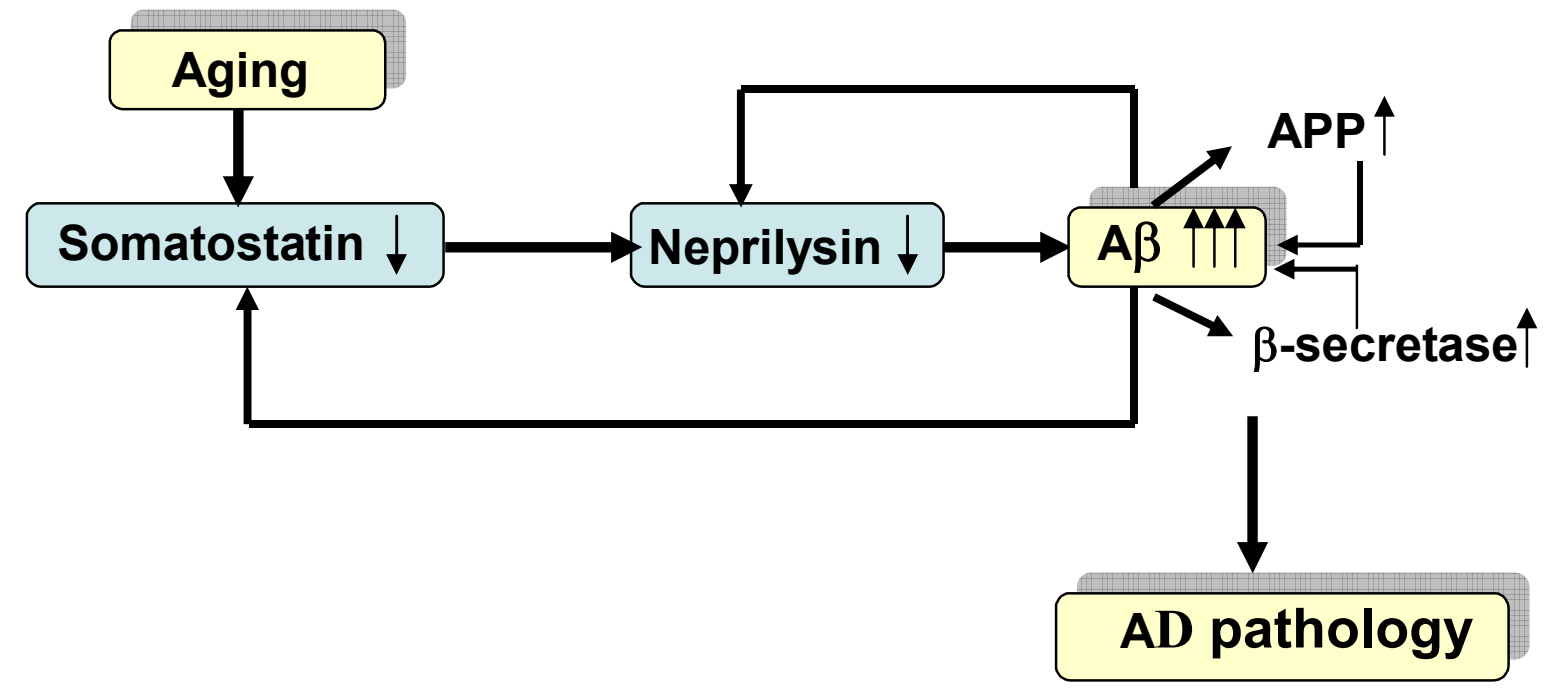

Figure 1. 


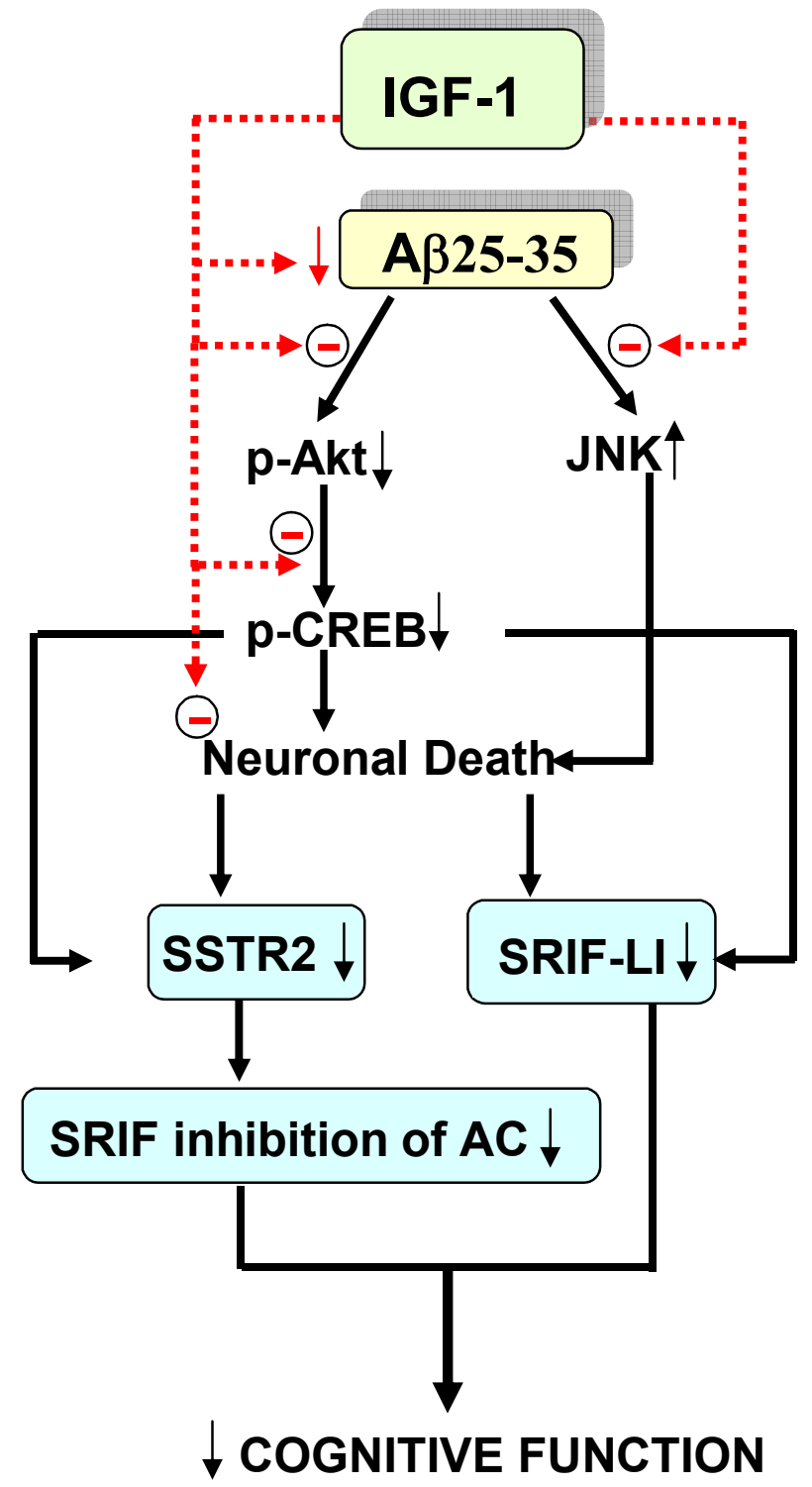

Fig.2. 


\section{LEGENDS TO FIGURES}

Figure 1. Relationship between somatostatin, neprilysin activity, $A \beta$ levels, aging and Alzheimer's disease (taken from Hama and Saido, 2005). $\downarrow$ : decrease; $\uparrow$ : increase

Figure 2. Impairment of the somatostatinergic system by $A \beta 25-35$ and protective effects of IGF-I in the temporal cortex. Solid black arrows: mechanisms by which A $\beta 25$ 35 may impair the somatostatinergic system and, hence, cognitive function, in the temporal

cortex. $\downarrow$ : decrease $\uparrow$ : increase. Dashed red arrows: possible mechanisms by which IGF-1 treatment could prevent the A $\beta 25-35$-induced alterations of the somatostatinergic system, and hence, the impairment of cognitve function, in the temporal cortex. $\odot$ : prevention. 